\title{
PENERAPAN TEKNIK KLASIFIKASI PADA SISTEM REKOMENDASI MENGGUNAKAN ALGORITMA GENETIKA
}

\author{
Rita Rismala $^{1}$, Mahmud Dwi Sulistiyo ${ }^{2}$ \\ Program Studi S1 Teknik Informatika, Fakultas Informatika \\ Universitas Telkom ${ }^{1,2}$ \\ Jl. Telekomunikasi - Terusan Buah Batu - Bandung 40257, Jawa Barat, Indonesia ${ }^{1,2}$ \\ ritaris@telkomuniversity.ac.id ${ }^{1}$, mahmuddwis@ elkomuniversity.ac.id ${ }^{2}$
}

\begin{abstract}
Abstrak
Sistem rekomendasi yang dibangun dalam penelitian ini adalah sistem rekomendasi yang dapat memberikan rekomendasi sebuah item terbaik kepada user. Dari sisi data mining, pembangunan sistem rekomendasi satu item ini dapat dipandang sebagai upaya untuk membangun sebuah model classifier yang dapat digunakan untuk mengelompokkan data ke dalam satu kelas tertentu. Model classifier yang digunakan bersifat linier. Untuk menghasilkan konfigurasi model classifier yang optimal digunakan Algoritma Genetika (AG). Performansi AG dalam melakukan optimasi pada model klasifikasi linier yang digunakan cukup dapat diterima. Untuk dataset yang digunakan dengan kombinasi nilai parameter terbaik yaitu yaitu ukuran populasi 50 , probabilitas crossover 0.7 , dan probabilitas mutasi 0.1 , diperoleh rata-rata akurasi sebesar $72.80 \%$ dengan rata-rata waktu proses 6.04 detik, sehingga penerapan teknik klasifikasi menggunakan AG dapat menjadi solusi alternatif dalam membangun sebuah sistem rekomendasi, namun dengan tetap memperhatikan pengaturan nilai parameter yang sesuai dengan permasalahan yang dihadapi.
\end{abstract}

Kata kunci:

sistem rekomendasi, klasifikasi, Algoritma Genetika

\begin{abstract}
In this study was developed a recommendation system that can recommend top-one item to a user. In terms of data mining, it can be seen as a problem to develop a classifier model that can be used to classify data into one particular class. The model used was a linear classifier. To produce the optimal configuration of classifier model was used Genetic Algorithm (GA). GA performance in optimizing the linear classification model was acceptable. Using the case study dataset and combination of the best
\end{abstract}

parameter value, namely population size 50, crossover probability 0.7 and mutation probability 0.1 , obtained average accuracy $72.80 \%$ and average processing time of 6.04 seconds, so that the implementation of classification techniques using GA can be an alternative solution in developing a recommender system, due regard to setting the parameter value depend on the encountered problem.

Keywords:

Recommendation system, classification, Genetic Algorithm

\section{Pendahuluan}

Klasifikasi merupakan salah satu teknik dasar dalam bidang data mining. Teknik klasifikasi diperlukan untuk dapat melakukan pengenalan pola, prediksi nilai, hingga pengambilan keputusan. Dalam hal pengambilan keputusan, diperlukan sistem rekomendasi yang berperan dalam memberikan rekomendasi sejumlah item kepada user sehingga dapat membantu user dalam mengambil keputusan. Adapun sistem rekomendasi yang dibangun dalam penelitian ini adalah sistem rekomendasi yang dapat memberikan rekomendasi sebuah item kepada user. Pendekatan yang umumnya digunakan untuk membangun sebuah sistem rekomendasi diantaranya content-based, collaborative, dan hybrid (Adomavicius \& Tuzhilin, 2005). Namun dari sisi data mining, pembangunan sistem rekomendasi satu item ini dapat dipandang sebagai upaya untuk membangun sebuah model classifier yang dapat digunakan untuk mengelompokkan data ke dalam satu kelas tertentu. Untuk menghasilkan model classifier dengan performansi tinggi, umumnya harus melalui mekanisme yang kompleks. Hal ini tentu berpengaruh terhadap semakin "mahal"-nya biaya komputasi yang dibutuhkan untuk membangun model 
tersebut. Terkait dengan hal tersebut, maka pada penelitian ini dibangun model classifier yang sederhana, namun dapat menghasilkan performansi yang cukup baik dan tetap menjaga biaya komputasi yang "rendah".

Agar model classifier memiliki performansi yang baik, maka dibutuhkan tahap pembelajaran untuk menghasilkan konfigurasi yang optimal. Jika dikaitkan dengan permasalahan di dunia kecerdasan buatan, proses ini dapat dipandang sebagai permasalahan optimasi. Oleh sebab itu, algoritmaalgoritma optimasi dapat digunakan sebagai alternatif cara untuk membangun model classifier. Sejauh ini, Algoritma Genetika merupakan algoritma optimasi yang telah diaplikasikan secara luas dalam bidang engineering karena kemampuannya yang cukup powerful untuk menemukan solusi optimal dalam waktu yang relatif cepat (Hegerty \& Kasprak, 2009). Selain itu, dalam penelitian (Widodo \& Mahmudy, 2010) juga didapatkan bahwa waktu proses Algoritma Genetika untuk menyelesaikan permasalahan kombinatorial pada sistem rekomendasi wisata kuliner terbukti cukup cepat. Oleh karena itu, pada penelitian ini digunakan Algoritma Genetika untuk membangun sistem rekomendasi dengan menerapkan teknik klasifikasi.

\section{KAJIAN LITERATUR}

\section{II.1. Sistem Rekomendasi}

Sistem rekomendasi memberikan rekomendasi item kepada user dengan cara menganalisis data user serta informasi lain yang berhubungan dengan user tersebut, seperti informasi mengenai user lain yang memiliki preferensi yang sama atau informasi mengenai environment dari user tersebut (Sebastia, Garcia, Onaindia, \& Guzman, 2009). Terdapat dua fungsi utama sistem rekomendasi: (1) Rekomendasi top- $N$ item, yaitu sistem rekomendasi memberikan daftar $\mathrm{N}$ item yang paling direkomendasikan untuk user. (2) Prediksi rating, yaitu memprediksi preference score dari seorang user untuk item tertentu (Thai-Nghe, Drumond, Krohn-Grimberghe, $\&$ Schmidt-Thieme, 2010).

\section{II.2. Klasifikasi}

Klasifikasi merupakan salah satu teknik dasar dalam data mining yang saat ini masih menjadi open topic terutama untuk dimensi data yang besar (Yang $\& \mathrm{Wu}, 2006)$. Proses pembelajaran dalam klasifikasi dilakukan untuk membangun model classifier berdasarkan data latih sehingga dapat digunakan untuk mengklasifikasikan data "masa depan" (Fung, Wang, \& Yu, 2007). Jika dipandang dari dunia kecerdasan buatan, proses ini dapat dipandang sebagai permasalahan optimasi untuk mendapatkan model classifier yang dapat meminimumkan error klasifikasi.

\section{II.3. Algoritma Genetika}

Algoritma Genetika (AG) telah diaplikasikan secara luas dalam bidang engineering. Pada AG, kandidat solusi untuk suatu permasalahan direpresentasikan dalam bentuk kromosom. Kemudian kromosom tersebut dievolusi dengan menerapkan tiga operator genetika yaitu rekombinasi, mutasi dan seleksi, untuk menghasilkan kandidat solusi yang lebih baik. Beberapa nilai parameter perlu diatur agar AG berjalan secara optimal, diantaranya: ukuran populasi, maksimum iterasi, jenis seleksi, jenis dan probabilitas rekombinasi, serta jenis dan probabilitas mutasi (Kachitvichyanukul, 2012). AG dalam bentuk pseudocode dapat dilihat pada Kode 1 (Hegerty \& Kasprak, 2009).

\section{Kode 1. Pseudocode Algoritma Genetika}

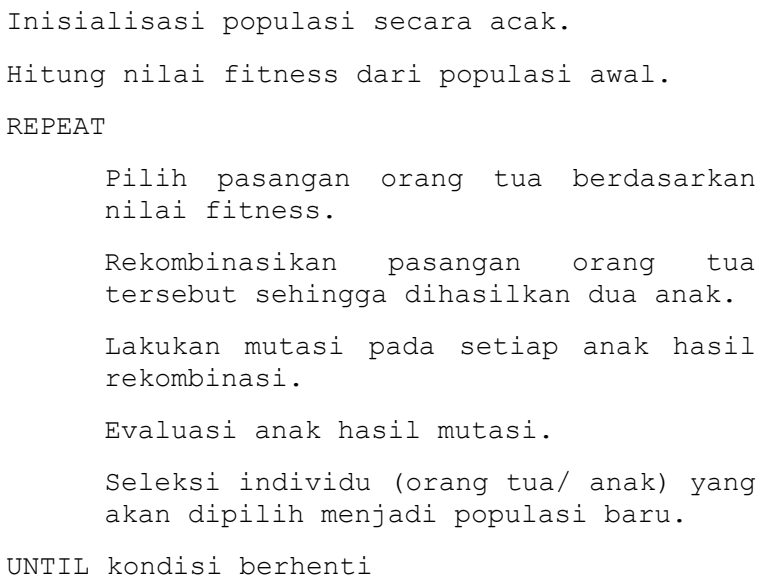

\section{Analisis dan Perancangan}

\section{III.1 Data}

Sistem rekomendasi yang dibangun sebagai studi kasus dalam penelitian ini adalah sistem rekomendasi 
pemilihan bidang keahlian tugas akhir. Data yang digunakan adalah data akademik mahasiswa Program Studi S1 Teknik Informatika Universitas Telkom dari tahun 2008 - 2013. Data ini berisi nilai-nilai mata kuliah yang telah diambil oleh mahasiswa beserta pilihan bidang keahlian dari setiap mahasiswa tersebut. Data bersifat non-linearly separable.

Sebelum diproses ke dalam sistem, data mentah di-preprocess terlebih dahulu dengan cara: (1) Mengubah data nilai indeks menjadi numerik, dengan ketentuan: $\mathrm{A}=4 ; \mathrm{B}=3 ; \mathrm{C}=2 ; \mathrm{D}=1 ; \mathrm{E}=0$. (2) Mengelompokkan mata kuliah (MK) menjadi MK dasar, MK bidang keahlian 1, MK bidang keahlian 2, dan MK bidang keahlian 3. (3) Menghitung rata-rata nilai MK untuk setiap kelompok. Atribut data hasil preprocessing dapat dilihat pada Tabel 1 . Kemudian data dibagi menjadi data latih dan data uji dengan proporsi 308 data latih dan 131 data uji.

Tabel 1. Atribut Data

\begin{tabular}{lccc}
\hline \hline \multicolumn{1}{c}{ Nama } & Kode & \multicolumn{1}{c}{ Nilai } & Keterangan \\
\hline \hline $\begin{array}{l}\text { MK dasar } \\
\text { MK bidang } \\
\text { keahlian 1 }\end{array}$ & $x_{1}$ & Real $[0 . .4]$ & \\
$\begin{array}{l}\text { MK bidang } \\
\text { keahlian 2 }\end{array}$ & $x_{2}$ & Real $[0 . .4]$ & Real $[0 . .4]$ \\
$\begin{array}{l}\text { MK bidang } \\
\text { keahlian 3 }\end{array}$ & $x_{4}$ & $\begin{array}{l}\text { Real }[0 . .4] \\
\text { bidang keahlian } \\
1=1, \text { bidang } \\
\text { keahlian 2 }=2, \\
\text { bidang keahlian } \\
3=3\end{array}$ & Keluaran \\
Kelas & T & \\
\hline \hline
\end{tabular}

\section{III.2 Model Klasifikasi}

Penelitian ini menggunakan model klasifikasi linier seperti pada persamaan (1), (2), (3), dan (4).

$\begin{array}{ll}y_{1}=k_{11} x_{1}+k_{12} x_{2}+\ldots+k_{1 n} x_{n} & \ldots[1] \\ y_{2}=k_{21} x_{1}+k_{22} x_{2}+\ldots+k_{2 n} x_{n} & \ldots[2] \\ y_{3}=k_{31} x_{1}+k_{32} x_{2}+\ldots+k_{3 n} x_{n} & \ldots[3]\end{array}$

$T \begin{cases}1 & ; \max \left(y_{1}, y_{2}, y_{3}\right)=y_{1} \\ 2 & ; \max \left(y_{1}, y_{2}, y_{3}\right)=y_{2} \\ 3 & ; \max \left(y_{1}, y_{2}, y_{3}\right)=y_{3}\end{cases}$

yang mana: $y_{1}:$ nilai kelayakan untuk kelas 1

$y_{2}$ : nilai kelayakan untuk kelas 2

$y_{3}$ : nilai kelayakan untuk kelas 3

$x_{1} . . x_{n}$ : atribut masukan

$k_{11} . . k_{l n}$ : bobot atribut masukan 1 s.d. n untuk nilai kelayakan kelas 1

$k_{21} . . k_{2 n}$ : bobot atribut masukan 1 s.d. n untuk nilai kelayakan kelas 2

$k_{31 .} . k_{3 n}$ : bobot atribut masukan 1 s.d. $\mathrm{n}$ untuk nilai kelayakan kelas 3

\section{III.3 Pemetaan Data Ke Dalam Sistem Rekomendasi}

Pada sistem rekomendasi, data yang tersedia dipetakan menjadi user, item, dan rating (Thai-Nghe, Drumond, Krohn-Grimberghe, \& Schmidt-Thieme, 2010). Dalam penelitian ini, mahasiswa dipetakan sebagai user, atribut data sebagai item, dan nilai atribut sebagai rating, seperti diilustrasikan pada Tabel 2. Proses untuk menentukan nilai kelayakan seperti dijelaskan pada sub-bab 2.2, dapat dipandang sebagai proses untuk menentukan rating untuk item $y_{1}, y_{2}$, dan $y_{3}$. Kemudian berdasarkan rating tersebut dilakukan proses klasifikasi untuk menentukan kelas yang sesuai bagi user.

Tabel 2. Matriks Pemetaan User - Item - Rating

\begin{tabular}{llllllll}
\hline \hline & $\boldsymbol{x}_{\boldsymbol{1}}$ & $\boldsymbol{x}_{\mathbf{2}}$ & $\boldsymbol{x}_{\mathbf{3}}$ & $\boldsymbol{x}_{\boldsymbol{4}}$ & $\boldsymbol{y}_{\boldsymbol{1}}$ & $\boldsymbol{y}_{\mathbf{2}}$ & $\boldsymbol{y}_{\mathbf{3}}$ \\
\hline Mhs 1 & 2,41 & 3,21 & 1,24 & 1,87 & $?$ & $?$ & $?$ \\
Mhs 2 & 3,12 & 1,98 & 1,76 & 4,00 & $?$ & $?$ & $?$ \\
Mhs 3 & 2,78 & 3,21 & 3,56 & 2,89 & $?$ & $?$ & $?$ \\
... & & & & & & & \\
Mhs n & 3,56 & 3,21 & 3,11 & 2,98 & $?$ & $?$ & $?$ \\
\hline \hline
\end{tabular}

\section{III.4 Perancangan Algoritma Genetika}

Algoritma Genetika (AG) berperan dalam menemukan nilai-nilai yang tepat untuk semua bobot pada model klasifikasi, sehingga mampu untuk mengklasifikasikan setiap pola data masukan ke dalam kelas-kelas yang sesuai dengan akurasi sebaik mungkin. Skema AG yang digunakan pada penelitian ini dapat dilihat pada Gambar 1. 


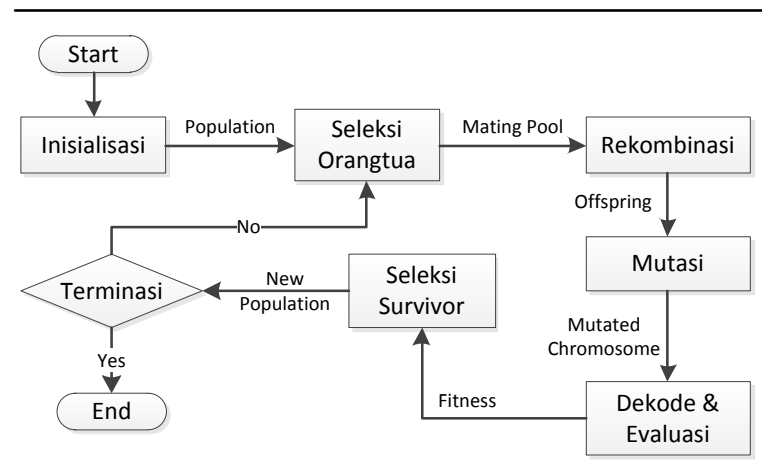

Gambar 1. Skema Algoritma Genetika

\section{III.4.1 REPRESENTASI KROMOSOM}

Representasi kromosom yang digunakan adalah representasi bilangan real, di mana setiap gen menyatakan nilai bobot untuk setiap atribut masukan pada model. Ilustrasi representasinya dapat dilihat pada Gambar 2.

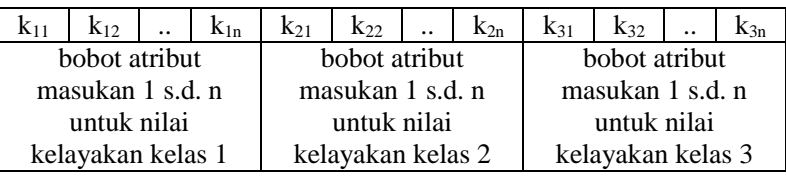

\section{Gambar 2. Representasi Kromosom pada GA}

\section{III.4.2 SELEKSI ORANG TUA}

Seleksi orangtua pada GA merupakan tahap memilih sejumlah pasangan kromosom untuk ditempatkan pada mating pool. Metode yang digunakan dalam penelitian ini adalah metode roulette wheel. Dengan metode ini, semakin tinggi nilai fitness suatu kromosom, maka peluang terpilihnya kromosom tersebut akan semakin besar.

\section{III.4.3 REKOMBINASI}

Pada tahap rekombinasi, digunakan cara pindah silang dengan menggunakan 1 titik potong yang ditentukan secara acak dengan probabilitas tertentu, sebagaimana diilustrasikan pada Gambar 3.
Kromosom Orang Tua

Kromosom Orang Tua 2

Kromosom Anak 1

Kromosom Anak 2

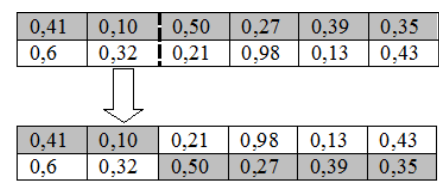

Gambar 3. Rekombinasi Satu Titik

\section{III.4.4 MUTASI}

Proses mutasi menggunakan metode mutasi nonuniform dengan probabilitas tertentu. Pada mutasi non-uniform dengan distribusi tetap, nilai gen hasil mutasi diperoleh dari nilai gen lama ditambah dengan bilangan real yang dibangkitkan secara acak dengan distribusi tertentu.

\section{III.4.5 SELEKSI SURVIVOR}

Pada tahap seleksi survivor, ada dua metode yang digunakan, yaitu generational replacement dan steady state. Dengan generational replacement, populasi lama digantikan oleh kromosom hasil elitisme dan kromosom-kromosom lain hasil rekombinasi dan mutasi. Adapun dengan steady state, populasi lama digabung dengan populasi baru dan dipilih berdasarkan fitness yang tertinggi.

\section{III.4.6 TERMINASI}

Untuk kriteria pemberhentian evolusi, terdapat dua kondisi, yaitu jika telah memenuhi maksimum generasi yang sudah ditentukan atau jika fitness terbaiknya tidak berubah-ubah selama sejumlah generasi berturut-turut.

\section{III.4.7 FUNGSI FITNESS}

Kromosom dievaluasi dengan menggunakan rumus fitness yang didefinisikan pada persamaan (5).

fitness $=\frac{n \text { TrueData }}{\text { nAllData }}$

yang mana:

nTrueData $=$ jumlah data yang terklasifikasikan dengan benar

nAllData $=$ jumlah semua data 


\section{Hasil dan Pembahasan}

Selama percobaan, dilakukan pelatihan melalui proses evolusi GA dengan menggunakan data latih, dan pengujian untuk melihat performansi model classifier yang sudah dilatih dengan menggunakan data uji, seperti dapat dilihat pada Gambar 4. Tujuan dari percobaan ini adalah untuk menganalisis pengaruh nilai-nilai parameter terhadap jalannya proses evolusi serta untuk mendapatkan kombinasi nilai parameter yang menghasilkan akurasi yang baik.

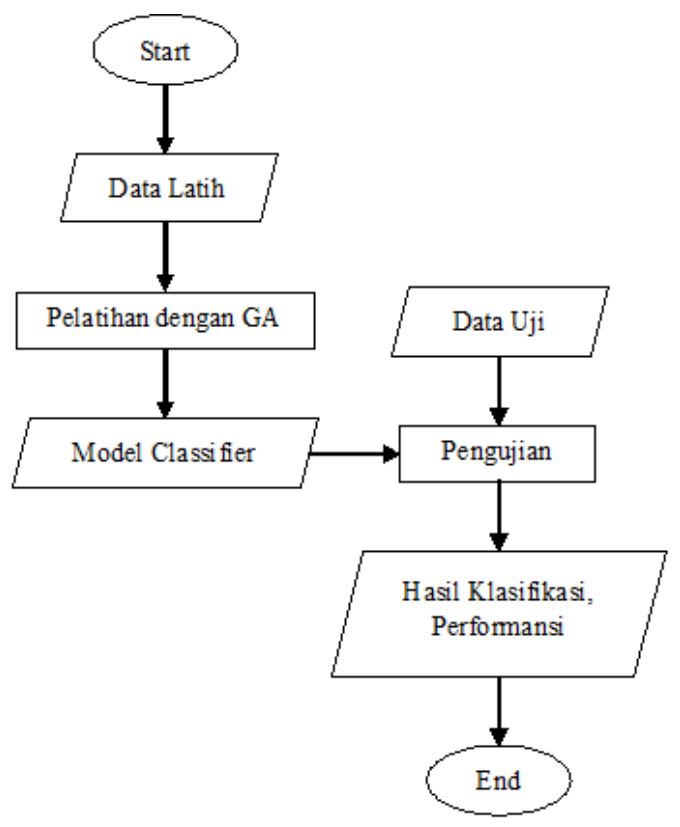

Gambar 4. Skema Percobaan

Adapun parameter yang diobservasi meliputi ukuran populasi, probabilitas crossover, dan probabilitas mutasi. Secara umum, hasil observasi setiap nilai parameter tertentu akan berpengaruh pada setting nilai untuk observasi parameter selanjutnya. Untuk setiap kombinasi nilai parameter dilakukan observasi sebanyak 10 kali.

Keterangan pada Tabel 3 s.d. Tabel 8: Ukpop = ukuran populasi; $\mathrm{Sel}=$ seleksi survivor (1: generational replacement, 2: steady state); $\mathrm{Pc}=$ probabilitas crossover; $\mathrm{Pm}=$ probabilitas mutasi; acc $\operatorname{Tr}=$ rata-rata tingkat akurasi data latih $(\%)$; accTs $=$ rata-rata tingkat akurasi data uji $(\%)$; accRata $=$ rata-rata tingkat akurasi acc $T r$ dan accTs, acc $=$ ratarata tingkat akurasi accRata untuk setiap nilai parameter, dan $\mathrm{Wkt}=$ rata-rata waktu proses (detik).

\section{IV.1 Observasi terhadap Ukuran Populasi}

Pada observasi GA tahap pertama, belum ada informasi terkait nilai-nilai parameter yang sebaiknya digunakan. Oleh karenanya, ditentukan nilai-nilai yang sudah umum digunakan, yaitu probabilitas crossover yang nilainya mendekati 1 , yaitu sebesar 0.9 dan probabilitas mutasi yang nilainya mendekati 0 , yaitu sebesar 0.1 .

Tabel 3. Hasil Observasi Pengaruh Ukuran Populasi terhadap Performansi Sistem

\begin{tabular}{cccccc}
\hline \hline \multicolumn{2}{c}{ Parameter } & \multicolumn{4}{c}{ Performansi } \\
Ukpop & Sel & accTr & accTs & accRata & Wkt \\
\hline \hline 5 & 1 & 51.69 & 50.76 & 51.41 & 0.35 \\
10 & 1 & 60.84 & 59.92 & 60.57 & 0.94 \\
20 & 1 & 69.9 & 67.56 & 69.20 & 2.35 \\
50 & 1 & 70.39 & 66.72 & 69.29 & 4.91 \\
5 & 2 & 55.36 & 52.67 & 54.56 & 0.31 \\
10 & 2 & 63.44 & 60.69 & 62.62 & 1.12 \\
20 & 2 & 66.92 & 64.89 & 66.31 & 2.44 \\
50 & 2 & 75.26 & 71.3 & 74.08 & 6.11 \\
\hline \hline
\end{tabular}

Dari data pada Tabel 3, dilakukan pengolahan hingga diperoleh rata-rata untuk tingkat akurasi dan waktu proses yang dihasilkan dari beberapa nilai ukuran populasi. Tingkat akurasi di sini menunjukkan kemampuan model dalam mengklasifikasikan data, baik pada proses latih maupun uji. Sedangkan waktu proses di sini menunjukkan kecepatan sistem menuju kondisi konvergen, sehingga solusi yang dihasilkan sudah tidak berubah lagi.

Tabel 4. Ringkasan Hasil Observasi untuk Setiap Ukuran Populasi

\begin{tabular}{lcccc}
\hline \hline Ukpop & $\mathbf{5}$ & $\mathbf{1 0}$ & $\mathbf{2 0}$ & $\mathbf{5 0}$ \\
\hline \hline Acc (\%) & 51.72 & 60.31 & 66.23 & $\mathbf{6 9 . 0 1}$ \\
Wkt (s) & $\mathbf{0 . 3 3}$ & 1.03 & 2.40 & 5.51 \\
\hline \hline
\end{tabular}



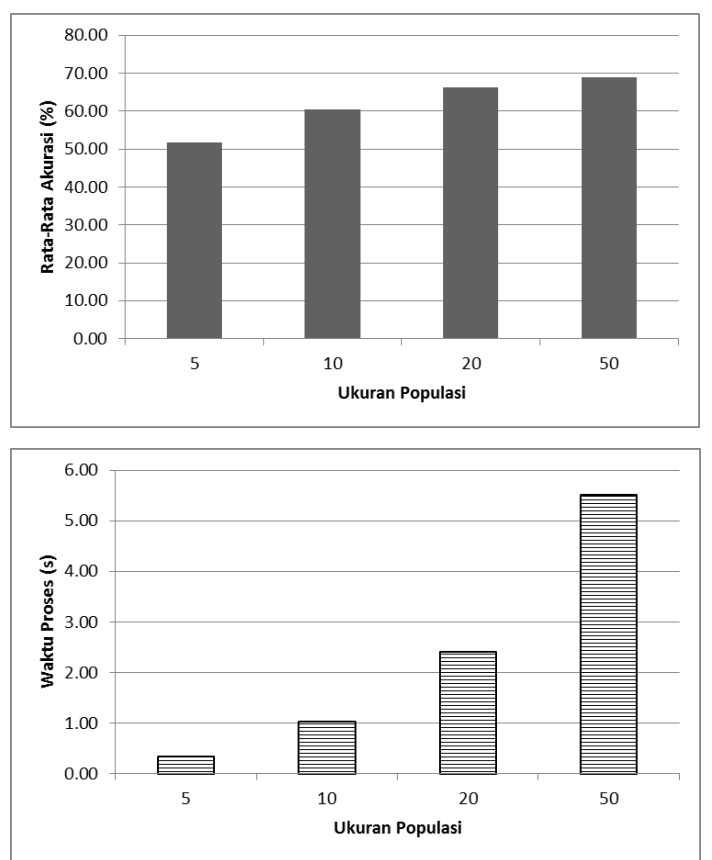

Gambar 5. Pengaruh Ukuran Populasi terhadap Performansi AG

Berdasarkan Tabel 4 dan Gambar 5, dalam hal tingkat akurasi terlihat bahwa semakin besar ukuran populasi, maka semakin bagus pula akurasi model. Dalam percobaan ini, nilai terbesar ukuran populasi yang digunakan adalah 50 dan pada nilai tersebutlah akurasi terbaik diperoleh. Hal ini dikarenakan ketika ukuran populasi yang digunakan semakin besar, maka jumlah sample yang diambil sebagai calon solusi pun semakin banyak. Hal tersebut tentu akan menambah kemungkinan diambilnya solusi yang terbaik di antara ruang solusi yang sangat besar. Namun, tidak ada jaminan bahwa jika ukuran populasi terus ditambah, maka akurasinya juga akan bertambah. Bisa jadi tingkat akurasi yang dihasilkan tidak akan beda jauh. Hal tersebut dapat diperkirakan dengan melihat akurasi yang tidak terlalu berbeda jauh antara ukuran populasi 20 dan 50.

Adapun jika melihat dari sisi waktu proses, terlihat bahwa semakin kecil ukuran populasi, semakin cepat pula proses pencarian yang dilakukan. Jika diasumsikan proses pencarian selalu berhenti karena telah mencapai maksimum generasi, hal ini sangat jelas karena dengan sedikitnya jumlah calon solusi yang dievaluasi, semakin cepat pula AG menyelesaikannya. Jika diasumsikan proses pencarian berhenti karena telah mencapai titik konvergen, maka dapat dipahami bahwa dengan jumlah sample yang diamati lebih sedikit, variasi calon solusi akan lebih sedikit, sehingga mengakibatkan konvergensi prematur akan lebih mudah terjadi. Jadi, cepatnya proses pencarian tersebut tidak menjamin kualitas solusi yang bagus. Oleh karenanya, nilai 50 sebagai ukuran populasi ini diambil untuk proses observasi selanjutnya.

\section{IV.2 Observasi terhadap Probabilitas Crossover}

Pada observasi tahap kedua ini, ukurang populasi yang digunakan adalah 50, sebagaimana hasil observasi terbaik pada tahap sebelumnya. Adapun untuk probabilitas mutasi, digunakan nilai default seperti tahap sebelumnya, yakni 0.1 .

Dari data pada Tabel 5, dilakukan pengolahan hingga diperoleh rata-rata untuk tingkat akurasi dan waktu proses yang dihasilkan dari beberapa nilai probabilitas crossover.

Berdasarkan Tabel 6 dan Gambar 6, dalam hal tingkat akurasi terlihat bahwa nilai probabilitas crossover $(\mathrm{Pc})$ terbaik adalah 0.7 . Pc berpengaruh terhadap munculnya individu-individu baru atau dalam hal ini berpengaruh terhadap kemampuan eksloratif GA. Semakin besar Pc, GA akan lebih eksploratif atau menyebar dalam proses pencariannya. Artinya, lebih besar pula kemungkinan untuk mendapatkan solusi yang lebih baik dari generasi ke generasi. Namun, sejauh ini tidak ada nilai Pc terbaik yang pasti untuk semua kasus optimasi karena sangat sangat dipengaruhi oleh kondisi data yang dihadapi. Dalam percobaan ini, terlihat bahwa akurasi GA naik ketika nilai Pc ditambah dari 0.5 menjadi 0.7. Namun, kondisinya malah berbalik ketika Pc terus ditambah hingga nilai maksimalnya, yaitu 1. Penurunan tersebut dimungkinkan terjadi karena saat GA menjadi sangat eksploratif, kemampuan GA untuk mencapai kondisi konvergen di titik dengan solusi yang optimal menjadi terpengaruh. Bisa jadi dengan kondisi data klasifikasi yang digunakan di sini, GA justru menjadi lebih sulit menentukan titik optimum global ketika persebaran calon solusinya sangat luas.

Adapun dari segi waktu proses, pada grafik terlihat hasil yang fluktuatif antara 0.5 sampai 0.9. Hal ini dapat dipandang bahwa Pc tidak berpengaruh terhadap waktu komputasi GA. Oleh sebab itu, nilai 0.7 diambil sebagai Pc untuk proses observasi selanjutnya. 
Tabel 5. Hasil Observasi Pengaruh Probabilitas Crossover terhadap Performansi Sistem

\begin{tabular}{cccccc}
\hline \multicolumn{3}{c}{ Parameter } & \multicolumn{4}{c}{ Performansi } \\
Pc & Sel & accTr & accTs & accRata & Wkt \\
\hline \hline 0.5 & 1 & 70.81 & 70.53 & 70.73 & 5.60 \\
0.7 & 1 & 72.56 & 71.76 & 72.32 & 6.10 \\
0.9 & 1 & 70.68 & 70.61 & 70.66 & 5.34 \\
1 & 1 & 70.75 & 69.39 & 70.34 & 5.46 \\
0.5 & 2 & 74.29 & 72.21 & 73.67 & 6.23 \\
0.7 & 2 & 75.1 & 73.05 & 74.49 & 8.10 \\
0.9 & 2 & 73.8 & 71.15 & 73.01 & 6.98 \\
1 & 2 & 73.44 & 72.75 & 73.23 & 6.39 \\
\hline \hline
\end{tabular}

Tabel 6. Ringkasan Hasil Observasi untuk Setiap Nilai Pc

\begin{tabular}{ccccc}
\hline \hline Pc & $\mathbf{0 . 5}$ & $\mathbf{0 . 7}$ & $\mathbf{0 . 9}$ & $\mathbf{1}$ \\
\hline \hline Acc (\%) & 72.20 & 73.40 & 71.83 & 71.79 \\
Wkt (s) & 5.91 & 7.10 & 6.16 & 5.92 \\
\hline \hline
\end{tabular}
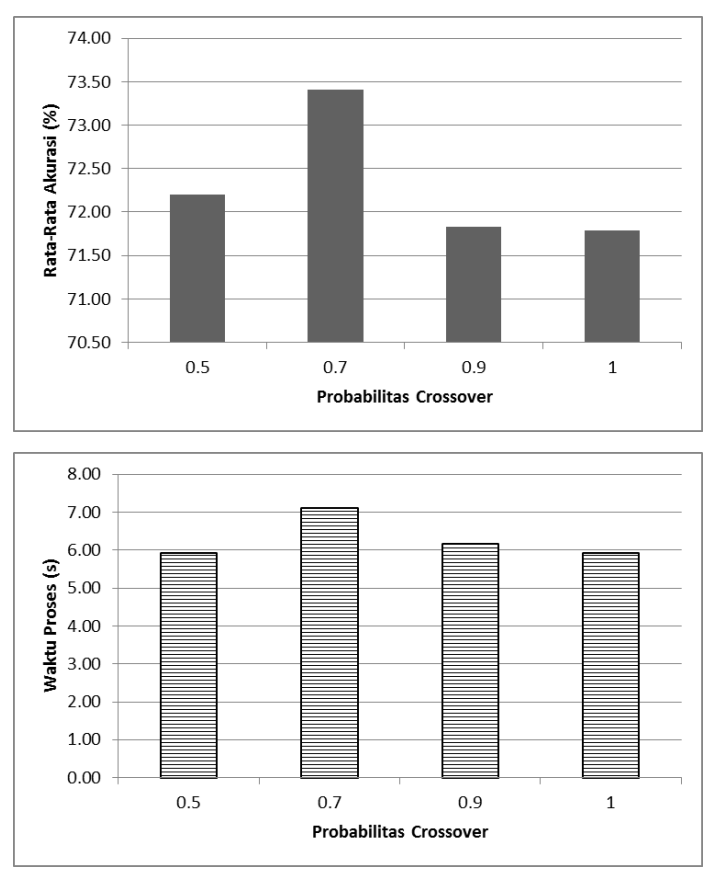

Gambar 6. Pengaruh Probabilitas Crossover terhadap Performansi GA

\section{IV.3 Observasi terhadap Probabilitas Mutasi}

Pada observasi ini, digunakan nilai tetap untuk beberapa parameter, yaitu ukuran populasi = 50 dan probabilitas crossover $=0.7$. Kedua nilai tersebut dipilih berdasarkan observasi di tahap sebelumnya, yang menghasilkan performansi terbaik di antara pilihan nilai lainnya.

Dari data pada Tabel 7, dilakukan pengolahan hingga diperoleh rata-rata untuk tingkat akurasi dan waktu proses yang dihasilkan dari beberapa nilai probabilitas mutasi.

Berdasarkan Tabel 8 dan Gambar 7, dari sisi keakuratan model terlihat jelas bahwa probabilitas mutasi (Pm) 0.1 memberikan hasil yang paling baik dibandingkan nilai-nilai yang lain. Proses mutasi pada GA memungkinkan sebuah kromosom menjadi lebih baik dengan mengubah beberapa nilai gen. Pm merupakan parameter untuk mengendalikan seberapa banyak gen yang akan dimutasi. Semakin besar nilai Pm, semakin besar kemungkinan dilakukannya mutasi untuk setiap gen, begitu pula sebaliknya. Mutasi pada banyak gen akan berdampak tidak baik karena dapat menyebabkan perubahan yang terlalu 'radikal'. Bisa jadi kromosom yang akan dimutasi sudah merepresentasikan solusi yang baik. Namun, karena terlalu banyak gen yang berubah, maka solusi yang sudah baik tersebut menjadi 'rusak'.

Adapun dari segi waktu proses, tidak adanya pola yang konsisten menunjukkan bahwa nilai Pm tidak berpengaruh terhadap kompleksitas algoritma. Artinya, besar kecilnya Pm hanya akan berpengaruh terhadap persebaran atau kualitas solusi yang dihasilkan, tidak pada kebutuhan algoritma akan waktu pemrosesan data. Dengan demikian, pada observasi ini diambil nilai 0.1 sebagai Pm yang memberikan performansi paling baik di antara nilainilai yang lainnya.

Tabel 7. Hasil Observasi Pengaruh Probabilitas Mutasi terhadap Performansi Sistem

\begin{tabular}{cccccc}
\hline \hline \multicolumn{2}{c}{ Parameter } & \multicolumn{4}{c}{ Performansi } \\
Pm & Sel & accTr & accTs & accRata & Wkt \\
\hline \hline 0.1 & 1 & 70.88 & 68.4 & 70.14 & 5.20 \\
0.3 & 1 & 72.11 & 71.68 & 71.98 & 5.11 \\
0.5 & 1 & 69.12 & 68.78 & 69.02 & 3.50 \\
0.7 & 1 & 69.64 & 71.07 & 70.07 & 4.17 \\
0.9 & 1 & 70.52 & 68.47 & 69.91 & 4.31
\end{tabular}

Rita Rismala, Mahmud Dwi Sulistiyo 


\begin{tabular}{llllll}
0.1 & 2 & 76.72 & 72.52 & 75.47 & 6.88 \\
0.3 & 2 & 71.53 & 69.77 & 71.00 & 4.79 \\
0.5 & 2 & 76.49 & 74.43 & 75.88 & 4.56 \\
0.7 & 2 & 72.08 & 71.76 & 71.98 & 3.67 \\
0.9 & 2 & 71.72 & 72.44 & 71.93 & 4.89 \\
\hline \hline
\end{tabular}

Tabel 8. Ringkasan Hasil Observasi untuk Setiap Nilai Pm

\begin{tabular}{cccccc}
\hline \hline Pm & $\mathbf{0 . 1}$ & $\mathbf{0 . 3}$ & $\mathbf{0 . 5}$ & $\mathbf{0 . 7}$ & $\mathbf{0 . 9}$ \\
\hline \hline Acc $(\%)$ & 72.80 & 71.49 & 72.45 & 71.03 & 70.92 \\
Wkt (s) & 6.04 & 4.95 & 4.03 & 3.92 & 4.60 \\
\hline \hline
\end{tabular}
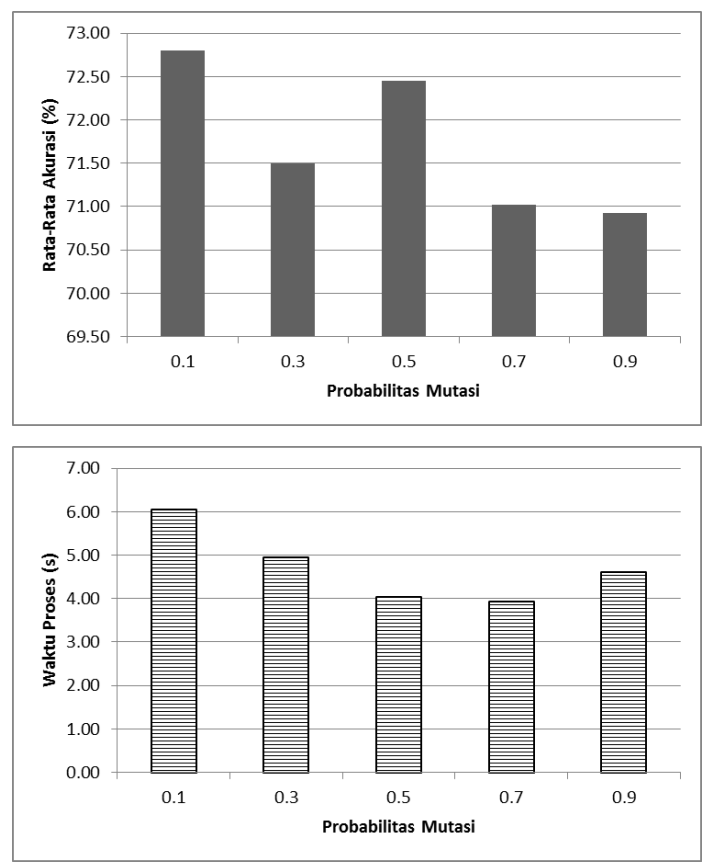

Gambar 7. Pengaruh Probabilitas Mutasi terhadap Performansi GA

Berdasarkan hasil observasi, dapat dilihat bahwa penerapan teknik klasifikasi menggunakan AG dapat menjadi solusi alternatif dalam membangun sebuah sistem rekomendasi, namun dengan tetap memperhatikan pengaturan nilai parameter yang sesuai dengan permasalahan yang dihadapi. Dalam penelitian ini, dengan menggunakan kombinasi nilai parameter terbaik yaitu ukuran populasi 50, probabilitas crossover 0.7 , dan probabilitas mutasi
0.1 , didapatkan rata-rata akurasi sebesar $72.80 \%$ dengan rata-rata waktu proses 6.04 detik. Hal ini menunjukkan bahwa performansi AG dalam membangun model classifier untuk data yang nonlinearly separable cukup dapat diterima.

\section{KESIMPULAN DAN SARAN}

Pada AG, parameter ukuran populasi, probabilitas crossover, dan probabilitas mutasi berpengaruh terhadap hasil yang diperoleh dari proses evolusi dipandang dari segi tingkat akurasi. Berdasarkan percobaan yang dilakukan, nilai terbaik untuk ketiga parameter tersebut berturut-turut adalah 50, 0.7, dan 0.1 . Adapun jika dipandang dari segi waktu proses, hanya ukuran populasi yang berpengaruh terhadap kompleksitas proses komputasi, sedangkan probabilitas crossover dan mutasi relatif tidak berpengaruh terhadap waktu proses yang dibutuhkan.

Dari percobaan dan analisis yang telah dilakukan, performansi AG dalam melakukan optimasi pada model klasifikasi linear yang digunakan cukup dapat diterima. Untuk dataset yang digunakan dengan kombinasi nilai parameter terbaik, diperoleh rata-rata akurasi sebesar $72.80 \%$ dengan rata-rata waktu proses 6.04 detik, sehingga penerapan teknik klasifikasi menggunakan AG dapat menjadi solusi alternatif dalam membangun sebuah sistem rekomendasi, namun dengan tetap memperhatikan pengaturan nilai parameter yang sesuai dengan permasalahan yang dihadapi.

Untuk keperluan pengembangan studi ke depannya, dapat digunakan model klasifikasi yang lebih kompleks dan dapat menangani berbagai kondisi persebaran data, baik yang linearly separable maupun non-linearly separable. Selain itu, dapat pula menggunakan metode optimasi lain, baik yang berbasis Evolutionary Algorithms maupun Swarm Intelligence.

\section{REFERENSI}

Adomavicius, G., \& Tuzhilin, A. (2005). Toward the next generation of recommender systems: A survey of the state-of-the-art and possible extensions. Knowledge and Data Engineering, IEEE Transactions on, 17(6), 734-749. 
Hegerty, B., Hung, C. C., \& Kasprak, K. (2009, November). A comparative study on differential evolution and genetic algorithms for some combinatorial problems. In Proceedings of 8th Mexican International Conference on Artificial Intelligence (pp. 913).

Widodo, A. W., \& Mahmudy, W. F. (2010). Penerapan algoritma genetika pada sistem rekomendasi wisata kuliner. Jurnal Ilmiah Kursor, 3(4), 205-2011.

Sebastia, L., Garcia, I., Onaindia, E., \& Guzman, C. (2009). e-Tourism: a tourist recommendation and planning application. International Journal on Artificial Intelligence Tools, 18(05), 717-738.

Thai-Nghe, N., Drumond, L., Krohn-Grimberghe, A., \& Schmidt-Thieme, L. (2010). Recommender system for predicting student performance. Procedia Computer Science, 1(2), 2811-2819.

Yang, Q., \& Wu, X. (2006). 10 challenging problems in data mining research. International Journal of Information Technology \& Decision Making, 5(04), 597-604.

Fung, B., Wang, K., \& Yu, P. S. (2007). Anonymizing classification data for privacy preservation. Knowledge and Data Engineering, IEEE Transactions on, 19(5), 711-725.

Kachitvichyanukul, V. (2012). Comparison of three evolutionary algorithms: GA, PSO, and DE. Industrial Engineering and Management Systems, 11(3), 215-223. 